\title{
Collective impacts on a global education emergency: The power of network response
}

\author{
Kate Moriarty ${ }^{1}$
}

Published online: 1 July 2020

(C) UNESCO IBE 2020

\begin{abstract}
The COVID-19 pandemic is an emergency of an exceptional scale, with major impacts on education globally and with significant new challenges for education in existing humanitarian contexts. This Viewpoint reflects on the immediate challenges of continuing education in humanitarian contexts and on the experience of the Inter-agency Network for Education in Emergencies (INEE) as a network supporting collective action of Education in Emergencies (EiE) practitioners globally. It also looks forward at INEE's plans to support quality distance education and issues to consider on the reopening of schools. It concludes with reflections on the needs and risks for EiE longer term.
\end{abstract}

Keywords Education in emergencies $\cdot$ COVID-19 $\cdot$ Pandemic $\cdot$ Conflict $\cdot$ Crisis

First formed in 2000, the Inter-agency Network for Education in Emergencies (INEE) has grown into a global network of more than 16,000 members in 190 countries. Its mission is to ensure that all individuals have the right to a quality, safe, relevant, and equitable education (INEE 2018). During the COVID-19-induced education crisis, the INEE has been taking action to support our members, partners, and communities by ensuring they are equipped to help their governments, schools, teachers, parents/caregivers, and students mitigate the effects of the crisis and support the continuity of education for children and youth.

While the COVID-19 pandemic has had major impacts on education globally, the challenges for education in existing humanitarian contexts are significantly greater. As INEE has responded to the escalating global education emergency, the INEE's priority has been

Thanks to INEE Secretariat staff—Charlotte Bergin, Lyndsay Bird, Natalie Brackett, Sarah Montgonery, and Dean Brooks, for their comments.

Kate Moriarty

kate.moriarty@inee.org

1 Inter-agency Network for Education in Emergencies (INEE), c/o International Rescue Committee, 122 East 42nd Street, 12th floor, New York, NY 10168, USA 
to keep a focus on continuing support for learning and well-being in light of school closures, in particular for children and youth already living in crisis and conflict contexts. For the estimated 75 million children who have their education disrupted to conflict and crisis every year (ODI 2016), the closure of schools due to COVID-19 brings multiple risks, in situations in which those primarily responsible for schooling are often ill-equipped to respond. Education in emergency contexts is life-saving and life-sustaining; it supports the mental health and wellbeing of children and youth.

Focusing on the most marginalized children in the context of conflict and (preCOVID) crisis situations has - and remains-INEE's priority during this global education emergency.

\section{Collective impact: The power of network response}

As the current COVID-19 education crisis unfolded, INEE members around the world responded. INEE stepped up actions to support the Education in Emergencies (EiE) community - as it has done over the last 20 years - through the curation of resources (INEE 2020a), a COVID-19 blog series (INEE 2020b), technical guidance (INEE 2020c), global advocacy materials (INEE 2020d; INEE, Save the Children, and UNICEF 2020), and the promotion of the INEE's Minimum Standards for Education: Preparedness, Response, Recovery (INEE 2010).

In February 2020, as school closures were beginning in Wuhan and other parts of China as a result of the COVID-19 virus, a number of INEE members and other key stakeholders sought to support the continuation of education for the affected children and young people. Within weeks, COVID-19 had become a global pandemic, with the number of students out of school worldwide reaching 1.5 billion, or $90 \%$ of all students (UNESCO 2020).

Among the first actions was the development of vetted resources to support the COVID19 education response. This collection of open-access materials ranged from Promising Practices for Equitable Remote Learning: Emerging Lessons from COVID-19 Education Responses in 127 Countries (Dreeseni et al. 2020) to specific guidance-Inclusive Education Sector Guiding Note on COVID-19 (Humanity \& Inclusion 2020), to resources for specific contexts, such as Coronavirus Prevention Campaign through Community Radios in Bangladesh (Bangladesh NGOs Network Communication 2020). These materials responded to the needs of our members, partners, and other stakeholders.

Sharing resources, tools, and guidance is also integral to how INEE supports its wide membership. The INEE highlighted existing tools, including the INEE Guidance Note on Psychosocial Support (McNatt et al. 2018) and developed new technical guidance "on how to respond rapidly to help support wellbeing and learning opportunities during the acute phase of the COVID-19 pandemic" (INEE 2020c). These resources and activities support the collective action of the INEE network to ensure that EiE actors, schools, and governments have access to the knowledge and capacity required to sustain continued education. This also included a strong focus on teacher wellbeing and capacity.

INEE members and the EiE and wider education-community were, and are, facing some of the most challenging contexts they have ever experienced, including mass school closures, social distancing restrictions, and increased mental health risks- not to mention protection issues for the children and youth living in conflict, displaced, and crisis settings. In response to demand, the INEE began a series of webinars to share knowledge and build capacity (INEE 2020e). Yet, their function was far greater. These webinars-held in all 
of INEE's core languages (Arabic, French, Portuguese, Spanish, and English), with the majority in English — created a space for connecting EiE actors and generated a sense of community and support, at a time when most countries had restrictions on movement and as everyone was adjusting to new ways of living and working.

As the global education community sought innovative remote responses to education in emergencies, through online learning, TV, radio, and other measures, it became evident that in some humanitarian contexts governments did not consider education a priority. In some refugee contexts, education was deprioritized and access to online education opportunities were denied. In some cases, even humanitarian coordination and funding mechanisms did not include education as a priority. INEE developed advocacy resources urging governments, donors, and all stakeholders to prioritize education in their COVID-19 responses, to protect children and young people through quality education and other measures, and to plan for safe reopening of schools (INEE 2020d), with recommendations for keeping children safe and learning, during and after the COVID-19 crisis (INEE, Save the Children, and UNICEF 2020).

\section{Response, recovery, and strengthening systems for future shocks}

The INEE minimum standards for education focus on preparedness, response, and recovery. It is clear that few, if any, governments had made sufficient preparation to mitigate the shock that COVID-19 has caused to society at large and to education systems specifically. Many children and young people will have lost parents, caregivers, and family friends, and experience much disruption to their daily lives. Quality education-including quality distance education - is a protective measure, supporting health education and mitigating the risk of exposure to child labour, violence, and exploitation.

The response of INEE and its members over the past four months will have a potential impact on education for hundreds of thousands of children and young people. However, as the latest data highlight, "[o]ver 500 million of the world's children and youth are not accessing distance learning alternatives" (Giannini 2020). Many countries are not even attempting to implement distance education, and many more only offer online provision (Giannini 2020), which is inaccessible for the most marginalized children. For example, $82 \%$ of learners worldwide do not have access to household internet and 56 million learners cannot use mobile phones to access information as they have no mobile coverage (UIS 2019). The poorest children, those with disabilities, refugee children and youth, girls and young women face barriers and discrimination in accessing online resources.

Although school closures have been necessary to reduce the transmission rate of COVID-19, one needs to consider the impact on the full indices of child development and wellbeing to make risk-informed decisions about the benefits and/or negative impact of school closures in order to safely plan for their reopening. In this evolving phase, the INEE is currently curating members' resources and collecting feedback on its recommended technical guidance with the aim to support the return to school where it is safe to do so.

As EiE practitioners have been highlighting, this is not our first emergency-but it is also not likely the last pandemic the world will face. Just as education actors looked to the Ebola emergency and other instances of widespread school closures for insights during the onset of COVID-19, the work we do today lays a foundation for future responses. It is key to document lessons learned and to plan ahead with new ways of working and preparedness in mind. 


\section{Risking the future: The right to education of children and youth in conflict and crisis}

2020 has seen millions of children missing out on their education. Even for children and young people in higher income countries, the impact on learning, on protection, on mental health and well-being is already being felt. School holidays alone have been shown to create a loss of " $20 \%$ and $50 \%$ of the skills [students] gained over the school year", even in high-income countries (The Economist 2020). For children and young in conflict crisis contexts, missing education will risk their futures and those of their community and country.

As governments grapple with plans for continuing education through response, recovery, and building-in future preparedness, political will and the financing of education will be critical. No doubt the swift response by education donors has been important in recent months; at the same time, however, overall funding for education as part of the United Nations COVID response Global Humanitarian Response Plan still requires urgent attention as the majority of funding requested remain unfunded (OCHA 2020). The significant gap between need and funding available has real-life consequences on students' education.

We still have much work to do to uphold the right to education, provide continuity of education, and ensure the safe return to school. All this will require prioritizing the planning needed to mitigate the long-term impacts on education. It is essential that the most vulnerable children and youth-including those who have never been to school or have already had their education disrupted by conflict or crisis—are not left even further behind.

\section{References}

Bangladesh NGOs Network for Radio and Communication (2020). Coronavirus prevention campaign through Community Radios in Bangladesh. https://bnnrc.net/covid-19/.

Dreeseni, T., Akseeri, S., Brossardi, M., Dewanii, P., Giraldoii, J. P., Kameii, A., et al. (2020). Promising practices for equitable remote learning Emerging lessons from COVID-19 education responses in 127 countries. Florence: UNICEF Innocenti.

Giannini, S. (2020, May 15). Distance learning denied. Blog post, UNESCO Global Education Monitoring Report. https://gemreportunesco.wordpress.com/2020/05/15/distance-learning-denied/.

Humanity \& Inclusion (2020). Inclusive education sector guiding note on COVID-19. https://www.hi-us. org/inclusive_governance_guidance_note_on_covid_19.

INEE [Inter-agency Network for Education in Emergencies] (2010). Minimum standards for education: Preparedness, response, recovery. New York, NY: INEE.

INEE (2018). Strategic framework 2018-2023. New York, NY: INEE.

INEE (2020a). Coronavirus (COVID-19) resources. https://inee.org/covid-19/resources.

INEE (2020b). COVID-19 blogs. https://inee.org/covid-19/blogs.

INEE (2020c). Technical note on education during the COVID-19 pandemic. https://inee.org/resources/ inee-technical-note-education-during-covid-19-pandemic.

INEE (2020d). Advocacy messages for education during COVID-19. https://inee.org/covid-19/advocacy.

INEE (2020e). Webinars. https://inee.org/covid-19/webinars.

INEE, Save the Children, \& UNICEF (2020, April 9). Learning must go on: COVID-19 advocacy brief. https://inee.org/resources/learning-must-go-covid-19-advocacy-brief.

McNatt, Z., Boothby, N., Wessells, M., \& Lo, R. (2018). INEE guidance note on psychosocial support. New York, NY: INEE.

ODI [Overseas Development Institute] (2016). Education cannot wait: A fund for education in emergencies. London: ODI.

OCHA [United Nations Office for the Coordination of Humanitarian Affairs] (2020). COVID-19 global humanitarian response plan. https://fts.unocha.org/appeals/952/summary. 
The Economist (2020, April 27). No more pencils, no more books: Closing schools for COVID-19 does lifelong harm and widens inequality. https://www.economist.com/international/2020/04/30/closing-schoo 1s-for-covid-19-does-lifelong-harm-and-widens-inequality.

UIS [UNESCO Institute of Statistics] (2019). Benchmarks: The forgotten commitment for accelerating progress towards SDG 4. https://www.sdg4education2030.org/taxonomy/term/77.

UNESCO (2020). COVID response website. https://en.unesco.org/covid19/educationresponse.

Publisher's Note Springer Nature remains neutral with regard to jurisdictional claims in published maps and institutional affiliations.

Kate Moriarty is Senior Advisor at the Inter-agency Network for Education in Emergencies (INEE), responsible for leading INEE's strategic engagement, dialogue and thought leadership globally and representing INEE in Europe. She has been working in the field of education for more than 20 years. In her early career, Kate worked as a human rights and adult educator, later focusing on policy and advocacy, working for a number of NGOs and the UN, including as Chief of Section for Peace and Human Rights Education at UNESCO. Kate is a qualified teacher, she also holds a BS in Sociology from the London School of Economics, and an MA in politics and development from the Institute of Latin American Studies. She completed a Doctorate in International Education at the University of Sussex; her research provides a critical examination of the policy formulation Sustainable Development Goal for Education (SDG 4) and unpacks the dimensions of quality and learning. 